\title{
Magnetic properties of sediments from Ocean Drilling Program sites 1109, 1115, and 1118 (Leg 180), Woodlark Basin (Papua New Guinea)
}

\author{
Naoto Ishikawa ${ }^{1}$ and Gina Marie Frost ${ }^{2}$ \\ ${ }^{1}$ Graduate School of Human and Environmental Studies, Kyoto University, Sakyo-ku, Kyoto 606-8501, Japan \\ ${ }^{2}$ Central Oregon Community College, 2600 NW College Way, Bend, OR 97701-5998, U.S.A.
}

(Received December 14, 2000; Revised July 24, 2002; Accepted July 30, 2002)

\begin{abstract}
Latest Miocene-Pleistocene synrift sediments at Ocean Drilling Program sites 1109, 1115, and 1118 (Leg 180), located on the hanging wall margin north of the Moresby fault in the Woodlark Basin, showed variations in magnetic parameters carried by magnetite and maghemite related to sedimentation process in the basin. At sites 1109 and 1115, an increase in the sedimentation rate at $3.8 \mathrm{Ma}$ was accompanied by the deposition of sediments with low ferrimagnetic mineral concentrations. An increase in the ferrimagnetic mineral concentrations occurred between 3.4 $\mathrm{Ma}$ and 3.2 Ma at the three sites. The onset age of the change became younger with distance from the subsidence center of the basin near the Moresby fault: 3.4 Ma at Site 1118, 3.3 Ma at Site 1109, and 3.2 Ma at Site 1115, which implies a northward onlapping of sediments with high ferrimagnetic mineral concentration. Sediments with finer-grained ferrimagnetic minerals were deposited between 2.3 and $2.0 \mathrm{Ma}$ at sites 1118 and 1109 and later, $2.8 \mathrm{Ma}$ at Site 1115 during a period of a low sedimentation rate. The upper parts of sites 1109 and 1115 had a diamagnetic contribution, which is attributed to relatively high concentrations of diamagnetic pelagic materials at a low sedimentation rate associated with the low frequency of turbidites.
\end{abstract}

\section{Introduction}

Rock magnetic parameters have often been used to analyze sedimentation processes (e.g., Thompson and Oldfield, 1986; King and Channell, 1991; Verosub and Roberts, 1995). Magnetic mineralogy and grain size and concentration of magnetic minerals documented by rock magnetic parameters are influenced by processes involved in transportation, deposition, or transformation of magnetic grains during sedimentation (e.g., Verosub and Roberts, 1995). We performed rock magnetic analysis on synrift sediments cored north of Moresby Seamount in the western Woodlark Basin, Papua New Guinea, during Leg 180 of the Ocean Drilling Program (Fig. 1) in order to reveal sedimentation processes during the formation of the Woodlark Basin from the viewpoint of magnetic property variations.

The Woodlark Basin forms a continuous system of active continental rifting evolving to seafloor spreading which began at $6 \mathrm{Ma}$ in the eastern part of the basin and the spreading center has been propagating westward ever since that time (Weissel et al., 1982; Taylor and Exon, 1987; Taylor et al., 1995, 1999a, 1999b). The present spreading tip is situated around the Moresby Seamount (Fig. 1). Continental rifting, producing full and half grabens, accommodates the extension around the seamount.

A low-angle normal fault, the Moresby fault, emerges along the northern flank of the seamount (Fig. 1). The hanging wall margin north of the normal fault has synrift sediments unconformably overlying prerift sediments

Copy right(c) The Society of Geomagnetism and Earth, Planetary and Space Sciences (SGEPSS); The Seismological Society of Japan; The Volcanological Society of Japan; The Geodetic Society of Japan; The Japanese Society for Planetary Sciences. and the basement sequence (Fig. 2). Cores were recovered at three locations on the northern margin of the Moresby Seamount (sites 1109, 1115, and 1118; Fig. 1) during Leg 180 , in order to determine the sedimentology, magnetobiostratigraphy, and vertical motion history of the synrift sediments. Biostratigraphic and paleomagnetic results provided well-constrained age-depth profiles (Fig. 3), which indicate a subsidence history on the northern margin of the Moresby Seamount associated with continental rifting (Taylor et al., 1999b; Takahashi et al., 2001).

In this paper, we present the magnetic properties of the synrift sediments and their variations, and discuss the relationship between magnetic property variations and the sedimentation processes at the three sites on the hanging wall margin. Magnetic susceptibility data at the three sites were obtained on board the Joides Resolution using a multisensor track during Leg 180 . The data sets are characterized by a first-order difference between low and high susceptibility zones (Figs. 5, 6, and 7; Taylor et al., 1999b). On-board analysis suggested that the transition from the low to high susceptibility zone occurred at about 3.2 Ma, which was approximately coeval for the three sites (Taylor et al., 1999b). The magnetic susceptibility variations reflect changes in the concentration of magnetic minerals and in magnetic mineralogy. Such changes are probably associated with fluctuations in sources of sediment supply and/or in supply routes associated with the rifting process. The magnetic properties presented in this paper will clarify the factors controlling the marked susceptibility variations and provide information concerning sedimentation processes related to the rifting in the western Woodlark Basin. 


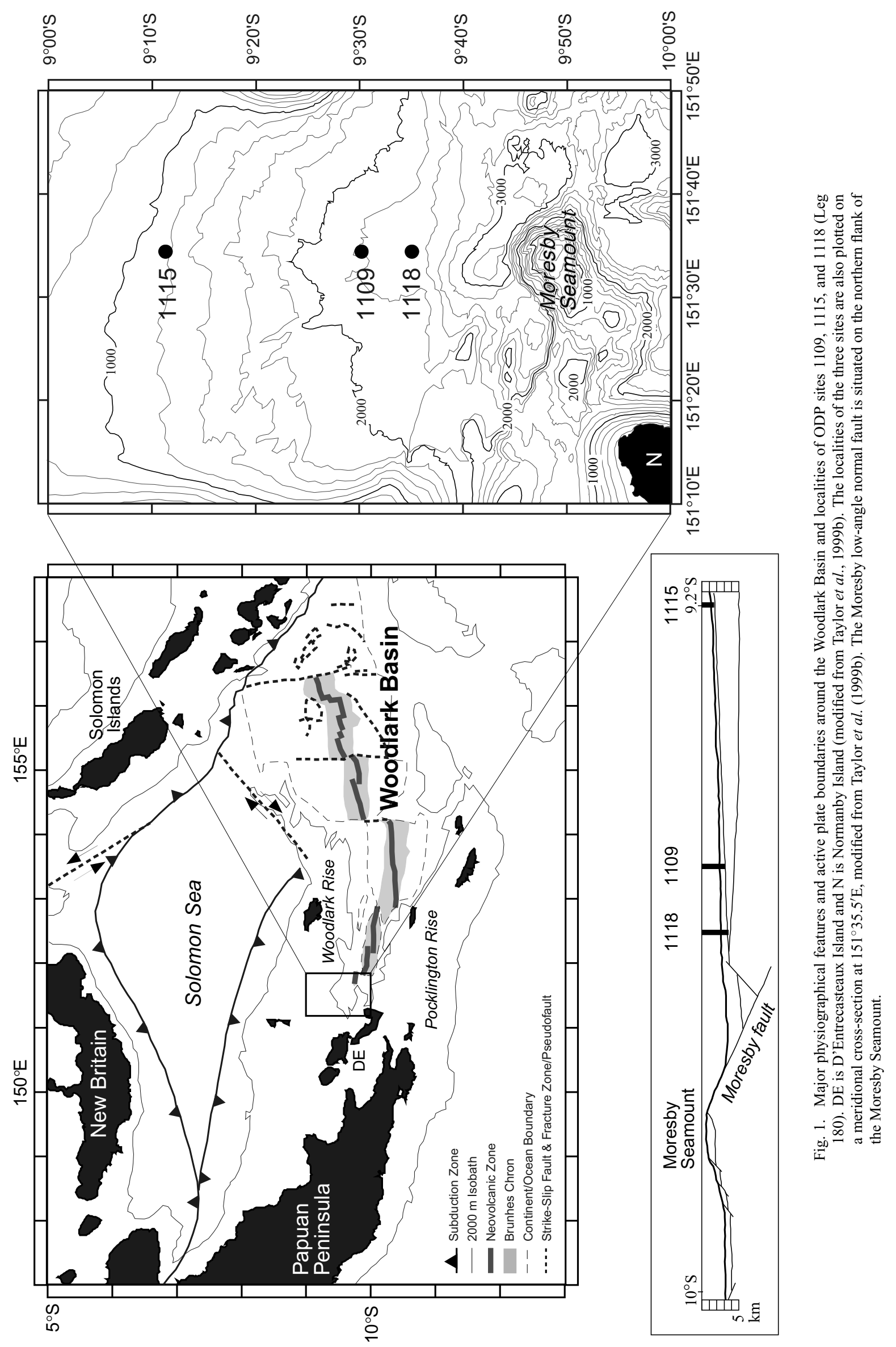



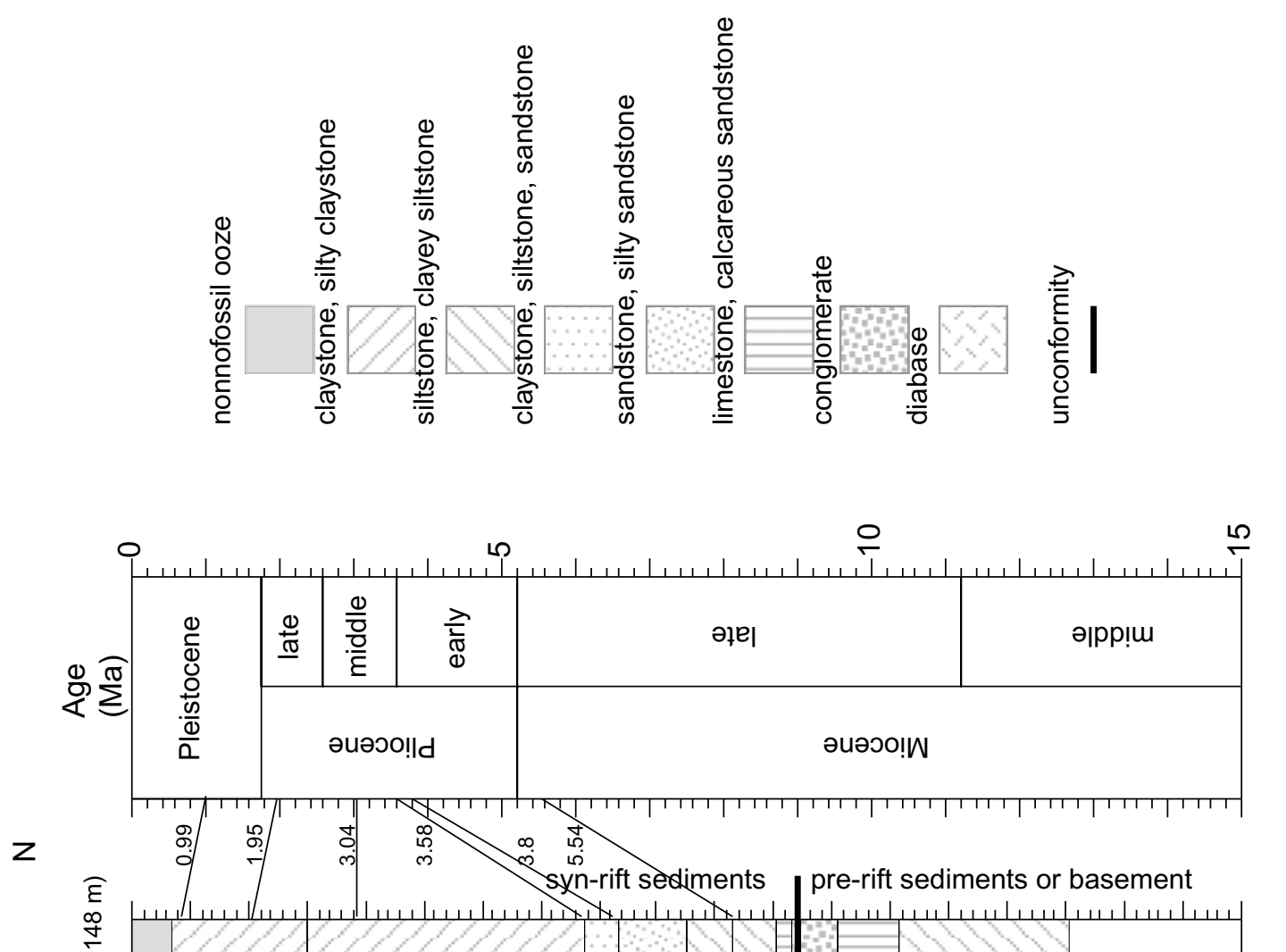

10
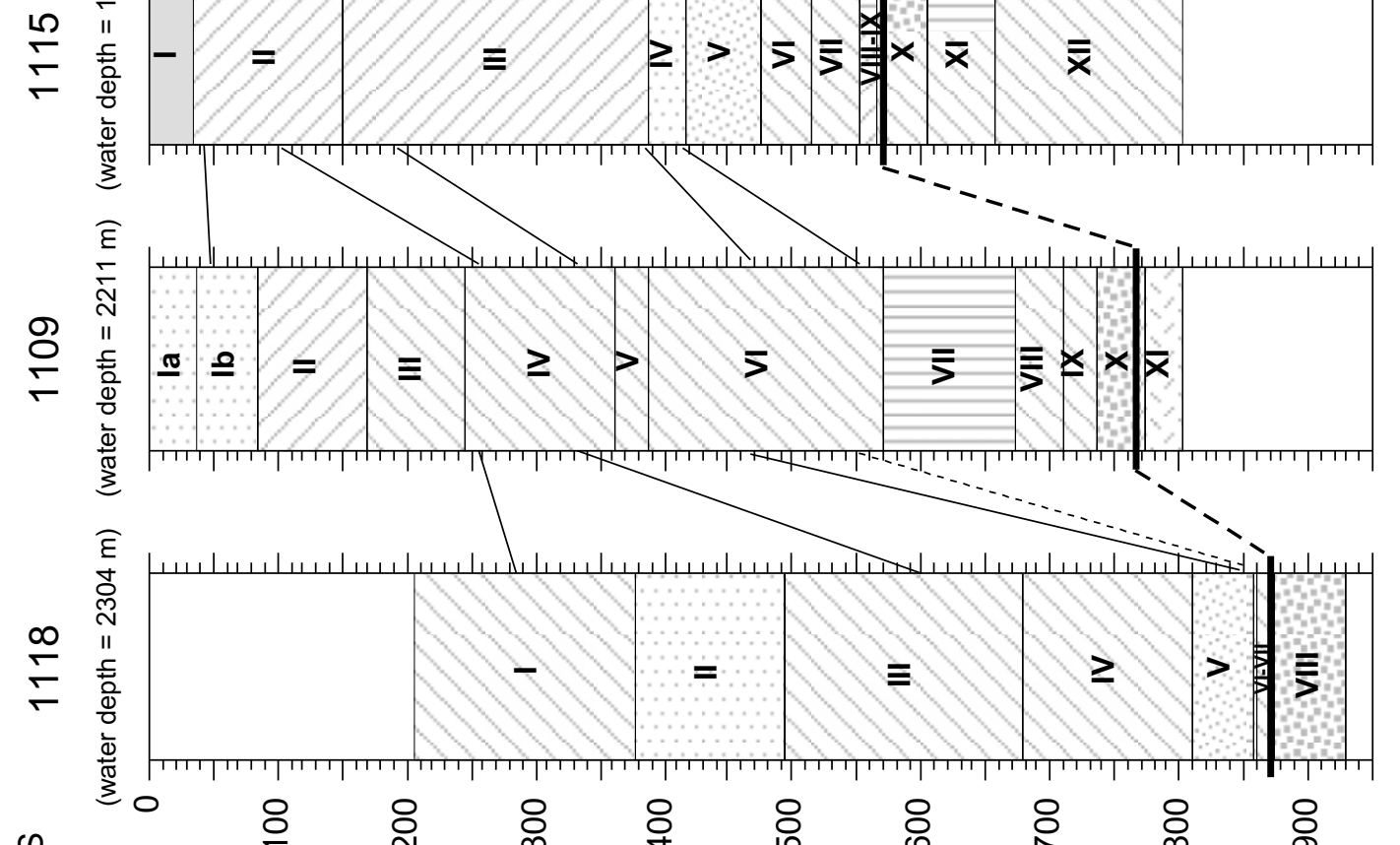

预 


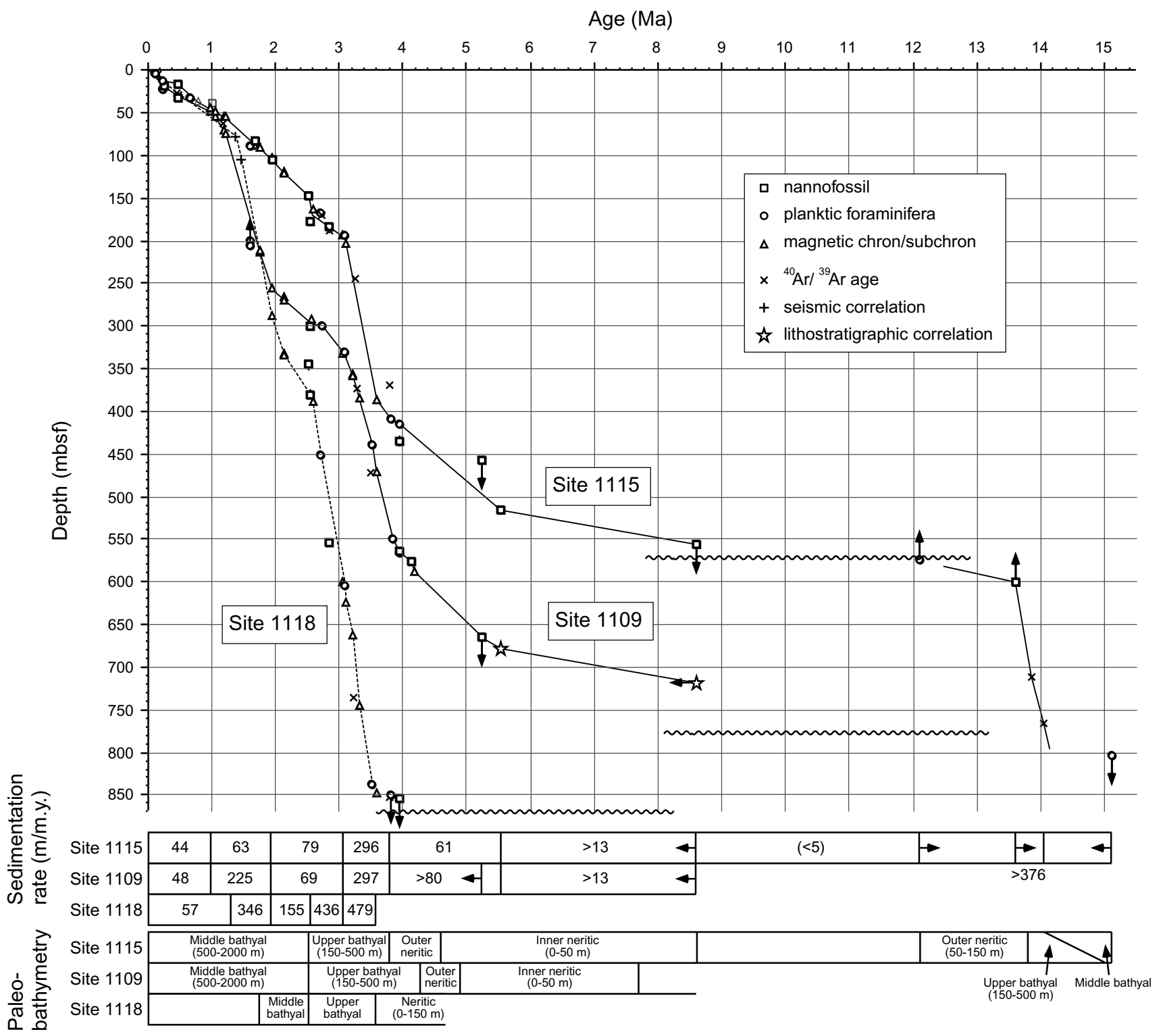

Fig. 3. Sedimentation curves, sedimentation rates, and paleobathymetry at sites 1109, 1115, and 1118, modified from Takahashi et al. (2001). Symbols with arrows indicate that the actual datum points could be above or below and older or younger than indicated by the symbols. Wavy lines denote unconformities.

\section{Samples}

During Leg 180, the northern margin sites (sites 1109, 1115, and 1118) penetrated the latest Miocene-Pleistocene synrift sequence and the prerift sections (Fig. 2; Taylor et $a l ., 1999 \mathrm{~b})$. We analyzed the synrift sediments of the three sites.

Site 1115 is located about $45 \mathrm{~km}$ north of the Moresby Seamount (Fig. 1). A $\sim 570 \mathrm{~m}$ thick sequence of latest Miocene to Pleistocene sediments was recovered, which was related to the subsidence of the northern margin during the rifting of the Woodlark Basin (Fig. 2). The synrift sequence unconformably overlies the middle Miocene Trobriand forearc sequence (units X-XII). The basal part of the synrift sequence from the unconformity at 574 to 513 mbsf (units VII-IX) consists of nonmarine conglomerate, organic-rich silty claystone from an inner lagoonal setting, and siltstone with shell fragments (open lagoon). Between 513 and 417 mbsf (units V and VI), inner neritic sandy siltstone and silty sandstone represent an open shelf setting. Above $417 \mathrm{mbsf}$ (units I-IV), turbidites were deposited in deep water (upper bathyal) and fine upward from sandy silty claystone to silty claystone. The section between $\sim 410$ and $\sim 190$ mbsf accumulated rapidly $(296 \mathrm{~m} / \mathrm{m}$.y.; Fig. 3). The sedimentation rate slowed from 79 to $44 \mathrm{~m} / \mathrm{m}$.y. above $\sim 190 \mathrm{mbsf}$, concurrent with subsidence to middle bathyal depths at around 169 mbsf. Pleistocene sediments above 36 mbsf (unit I) are dominated by nannofossil ooze with volcanic ash.

Site 1109 is located $11 \mathrm{~km}$ north of the Moresby Seamount (Fig. 1). About $730 \mathrm{~m}$ of sediments over a period from the latest Miocene to the Late Pleistocene were cored, which overlay $\sim 40 \mathrm{~m}$ of dolerite conglomerates (unit X) above a basement of massive dolerite sequence (unit XI) from 773 mbsf to $802 \mathrm{mbsf}$ (Fig. 2). The sediments record progressive subsidence, from subaerial to lagoonal, then shallow marine and deep water, over a period from the latest Miocene to the Late Pleistocene (Taylor et al., 1999b). Altered clay- 
rich sandstone and fine-grained sandstone were recovered between 737 to 709 mbsf (unit IX). The sedimentary facies indicates a non-marine, swampy environment. From 709 to 672 mbsf (unit VIII), silty claystone and clayey siltstone with shell, plant, and wood fragments, indicates a lagoonal setting. The sequence from 672 to $570 \mathrm{mbsf}$ (unit VII) reflects shallow marine sediments derived from volcanic and carbonate source materials. Between 570 and $388 \mathrm{mbsf}$ (unit VI), a succession of clay-rich siltstone and silty claystone interlayered with medium- to fine-grained sandstone was deposited rapidly $(297 \mathrm{~m} / \mathrm{m}$.y.) in upper bathyal water depths (Fig. 3), which represented hemipelagic carbonate muds with turbiditic sandstone interbeds. Clayey siltstones and silty claystones between 388 and 247 mbsf (units IV and $\mathrm{V}$ ) represented calcareous hemipelagic and fine-grained turbidite sediments. Sedimentation rates decreased to 69 $\mathrm{m} / \mathrm{m}$.y between 330 and $255 \mathrm{mbsf}$ (Fig. 3). Water depth reached middle bathyal above 285 mbsf. Between 247 and 48 mbsf (units III, II, and mostly Ib), distal silt-clay bioturbated turbidites with biogenic, volcanic and terrigenous components were deposited at a high accumulation rate of $216 \mathrm{~m} / \mathrm{m}$.y. Above $48 \mathrm{mbsf}$ (the upper part of unit $\mathrm{Ib}$ and unit Ia), calcareous clayey silt and silty clay with volcanic ash and nannofossil-rich, calcareous sand, silt and clay with volcaniclastic sand and volcanic ash, were deposited at low sedimentation rates $(48 \mathrm{~m} / \mathrm{m}$.y.).

Site 1118 is located $2 \mathrm{~km}$ north of Moresby Seamount. Core was recovered between depths of 205 and $\sim 927 \mathrm{mbsf}$ (Fig. 2). A dolerite conglomerate between 927 and 873 mbsf (unit VIII) is overlain by a sequence of lower Pliocene limestone, calcareous paraconglomerate, and volcanic sandstone which occurs up to $857 \mathrm{mbsf}$ (units VI and VII), and which was deposited in a marine lagoon. Above 857 mbsf (units IV), turbiditic and hemipelagic sedimentation was recorded. The sediments between 857 and 380 mbsf were deposited in upper bathyal depths, and the section above $380 \mathrm{mbsf}$ was deposited at middle bathyal depths (Fig. 3). The sequence comprises mixed volcaniclastic sandstones, siltstones and minor claystones, which are overlain by siltstones and claystones interbedded with turbiditic sandstones and siltstones (Fig. 2). Sedimentation rates were high between 857 and 388 mbsf (479 and $436 \mathrm{~m} / \mathrm{m} . \mathrm{y}$.), and decreased to $155 \mathrm{~m} / \mathrm{m}$.y. between 388 and $288 \mathrm{mbsf}$ (Fig. 3). A high accumulation rate of $317 \mathrm{~m} / \mathrm{m}$.y. was estimated in the section above $288 \mathrm{mbsf}$.

Analyzed samples were obtained from sediment cores from holes C and D at Site 1109, holes B and C at Site 1115, and Hole $\mathrm{A}$ at Site 1118. For shipboard measurements of natural remanent magnetization, we generally collected two cubic paleomagnetic samples $(2 \times 2 \times 2 \mathrm{~cm})$ from each core, or one sample in the case of low recovery. When we filled a cubic sample box, the small amount of excess sediment from the sampling tool was saved in a plastic bag. Sedimentary chips for rock magnetic measurements were prepared from the excess sediment. Rock magnetic measurements were performed on one or two chips from each core.

\section{Methods}

Rock magnetic parameters were obtained using 10-30 mg chips which were analyzed with an alternating gradient magnetometer (AGM, Model 2900-02, Princeton Measurements
Corporation) at Kyoto University. An initial magnetization (IM), hysteresis loop (HL), and direct-current demagnetization (DCD) of the saturation isothermal remanent magnetization (Mr) were measured. The maximum applied field was $1.0 \mathrm{~T}$.

For each IM, the following two values were determined: initial slope (IS) and high-field slope (HFS) values. The IS value indicates the incremental rate of induced magnetization acquired during application of the initial field, which reflects the low-field magnetic susceptibility. The HFS value was determined from the linear trend of the induced magnetization between 0.7 and $1.0 \mathrm{~T}$, and is influenced by paramagnetic, diamagnetic, and antiferromagnetic signals.

For each HL, the coercivity $\left(H_{c}\right)$, saturation magnetization $\left(M_{S}\right)$, and saturation remanent magnetization $\left(M_{r}\right)$ were determined after correction for the high-field slope between 0.7 $\mathrm{T}$ and 1.0 T, which includes paramagnetic, diamagnetic, and antiferromagnetic contributions. Field increments were $10 \mathrm{mT}$ in high fields between $0.5(-0.5)$ and $1.0(-1.0) \mathrm{T}$, $5 \mathrm{mT}$ between $0.1(-0.1)$ and $0.5(-0.5) \mathrm{T}$, and $2 \mathrm{mT}$ between 0.1 and $-0.1 \mathrm{~T}$. Instead of using the ratio of $M_{r}$ to magnetic susceptibility $(\kappa)$ after Thompson and Oldfield (1986), we calculated the ratio of $M_{r}$ to IS ( $\left.M_{r} / \mathrm{IS}\right)$, which was expected to show a change analogous to the $M_{r} / \kappa$ value with change in grain size of magnetite.

DCDs were measured at $2 \mathrm{mT}$ increments below $100 \mathrm{mT}$ in order to determine the coercivity of remanence $\left(H_{c r}\right)$. DCDs were also measured at $0.1 \mathrm{~T}$ increments up to $0.3 \mathrm{~T}$, which provided data for determination of $M_{r}$, isothermal remanent magnetization (IRM) backfield at $0.1 \mathrm{~T}$, and IRM backfield at $0.3 \mathrm{~T}$. The three values were used for calculation of S-ratios [i.e., $S(-0.1)$ and $S(-0.3)$ ] following the method of King and Channell (1991):

$$
\begin{aligned}
& S(-0.1)=-\left[\operatorname{IRM}(-0.1 \mathrm{~T}) / M_{r}\right] \\
& S(-0.3)=-\left[\operatorname{IRM}(-0.3 \mathrm{~T}) / M_{r}\right] .
\end{aligned}
$$

Strong-field thermomagnetic experiments were performed on selected samples using a horizontal thermomagnetic balance at Kyoto University. The samples were heated up to $700^{\circ} \mathrm{C}$ and cooled in air, in an applied field of $0.8 \mathrm{~T}$. The heating and cooling rates were about $8^{\circ} \mathrm{C} / \mathrm{min}$. Thermal demagnetization of composite IRMs (Lowrie, 1990) was also performed on the selected samples. The samples were packed in small quartz cups $(5 \mathrm{~mm}$ in diameter and $10 \mathrm{~mm}$ in height). A magnetic field of $2 \mathrm{~T}$ was applied along the cup axis, and then a field of $0.1 \mathrm{~T}$ was applied perpendicular to the axis. The IRMs were imparted with a pulse magnetizer (Magnetic Measurements Ltd. MMPM-9). The remanent magnetization was measured with a $2 \mathrm{G}$ Enterprises superconducting magnetometer (model 760R) at Kyoto University, using a non-magnetic Teflon holder, in the center of which the cups can be settled.

\section{Results}

\subsection{Rock magnetic parameters}

Variation in rock magnetic parameters in sediment cores at sites 1115, 1109, and 1118 are shown in Figs. 4, 5, and 6, respectively, including shipboard magnetic susceptibility (Taylor et al., 1999b). Typical results of HL experiments are shown in Fig. 7. 

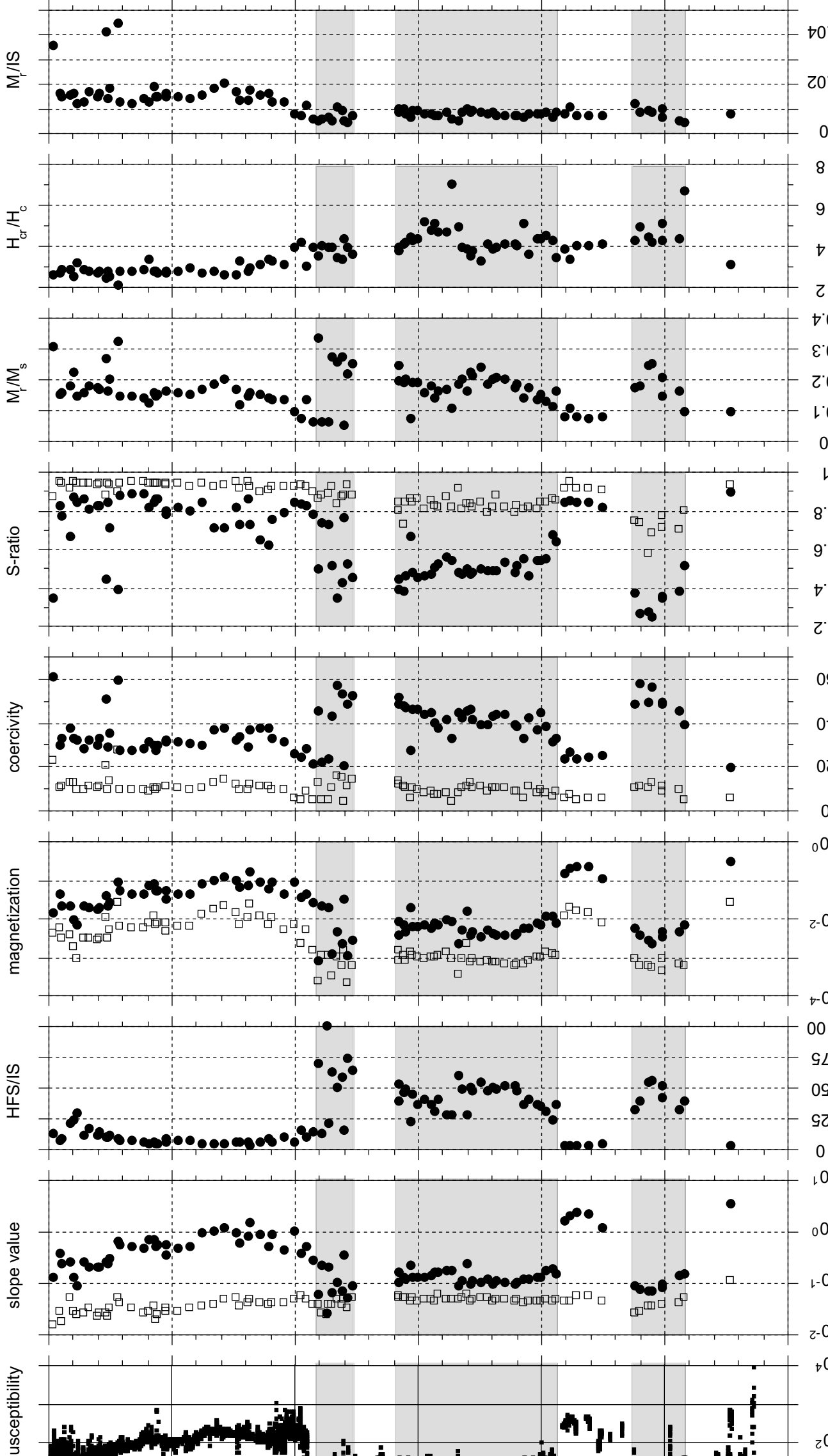

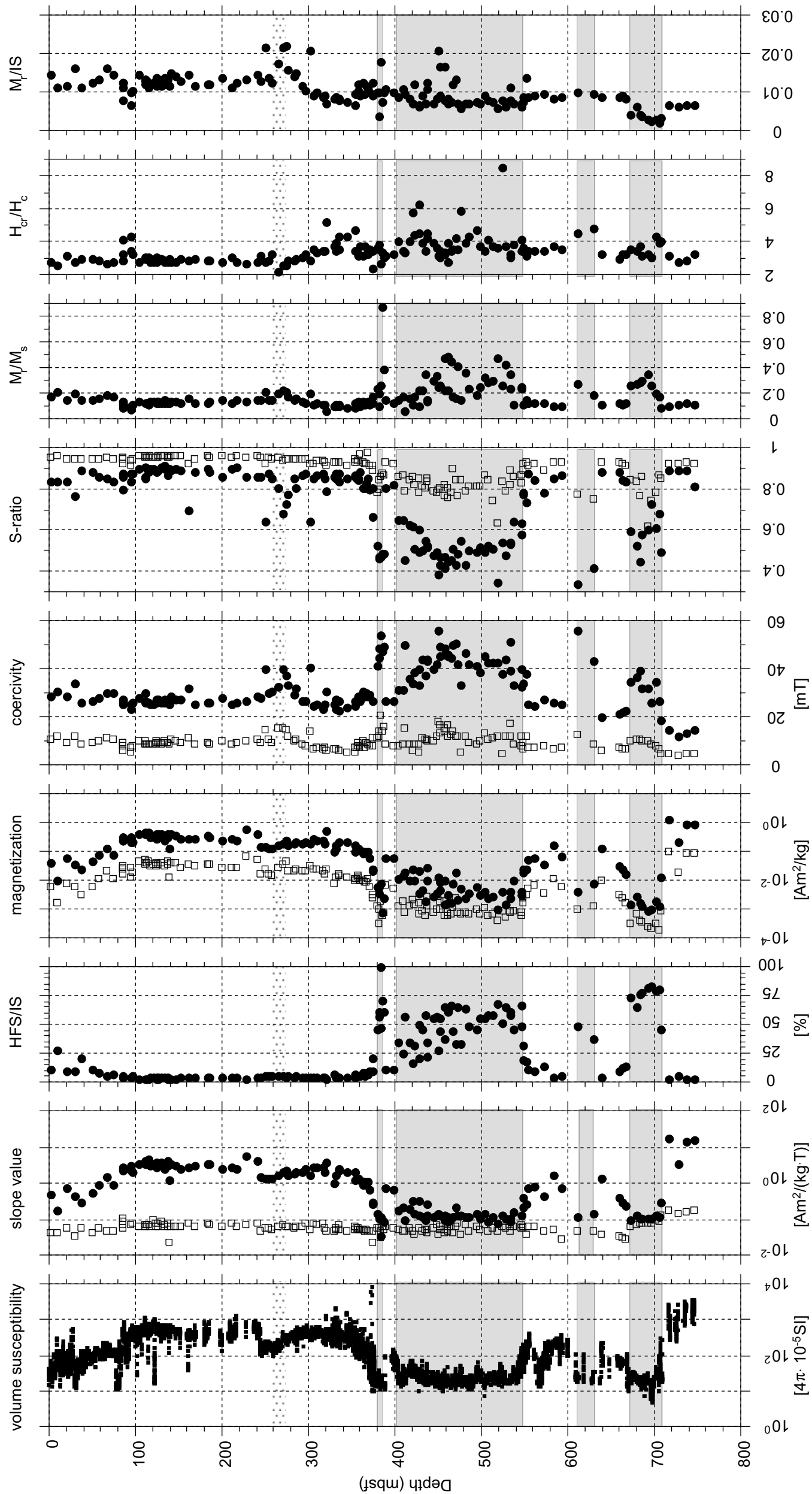

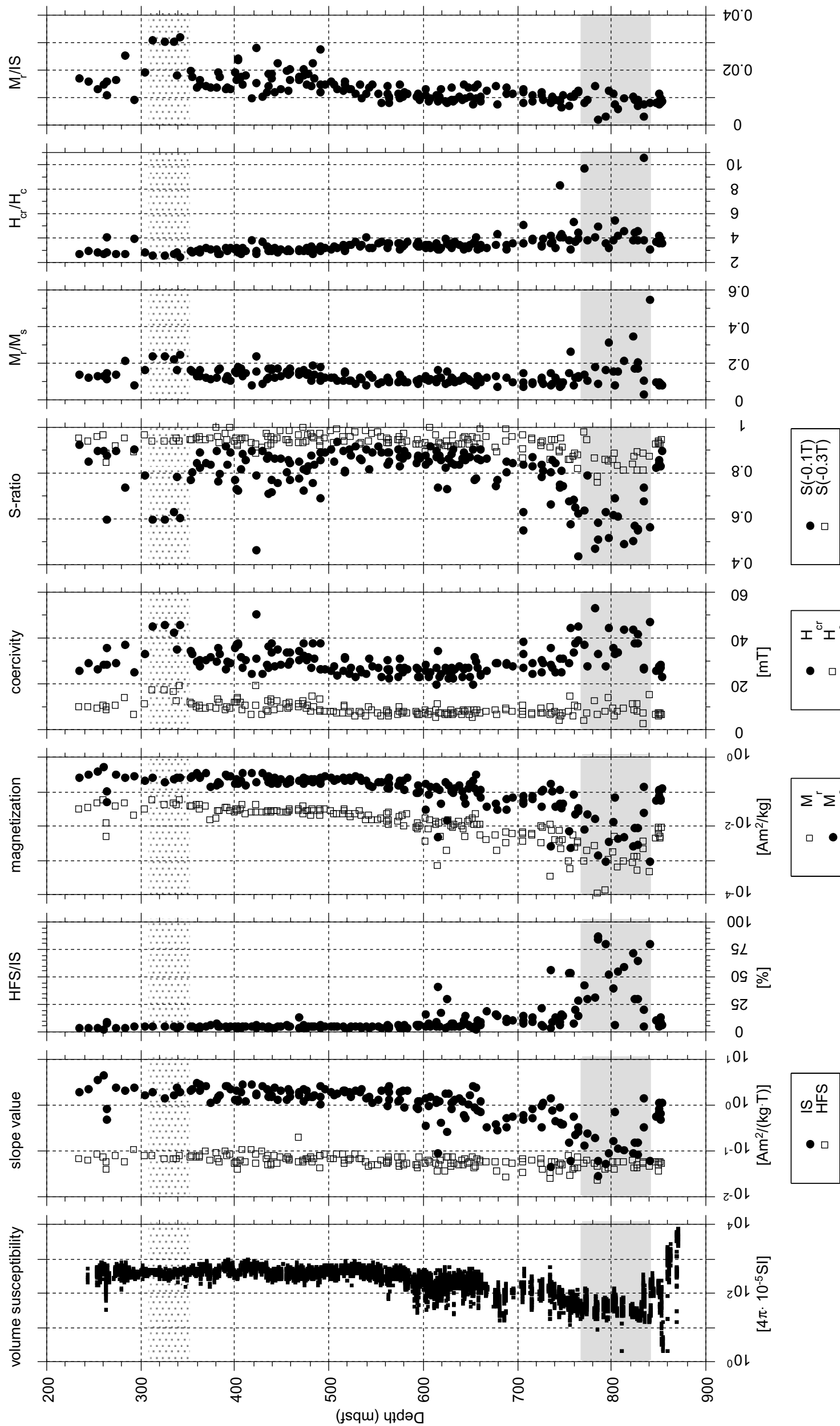
(a) 1109D-8R5, 19-21 cm (421.81 mbsf)

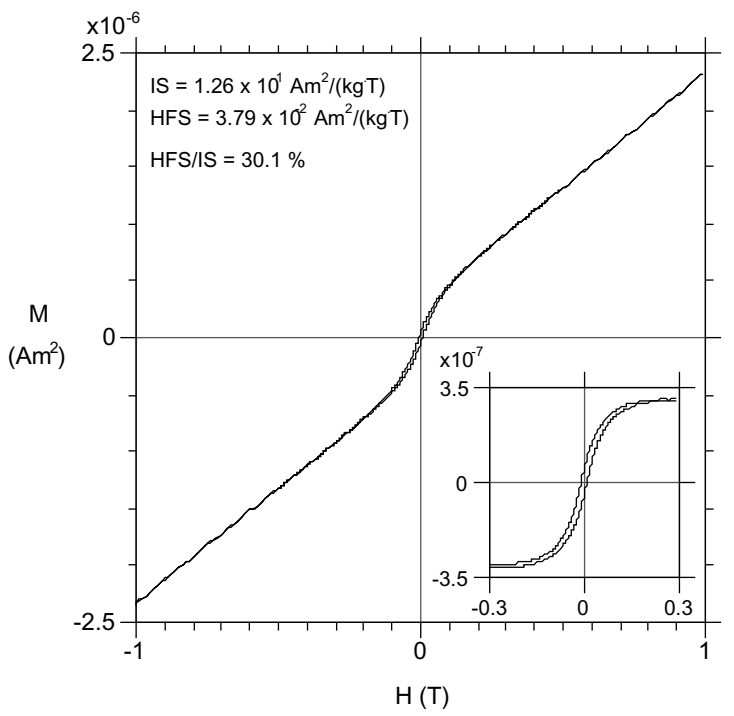

(c) $1109 \mathrm{C}-15 \times 5,19-21 \mathrm{~cm}(137.36 \mathrm{mbsf})$

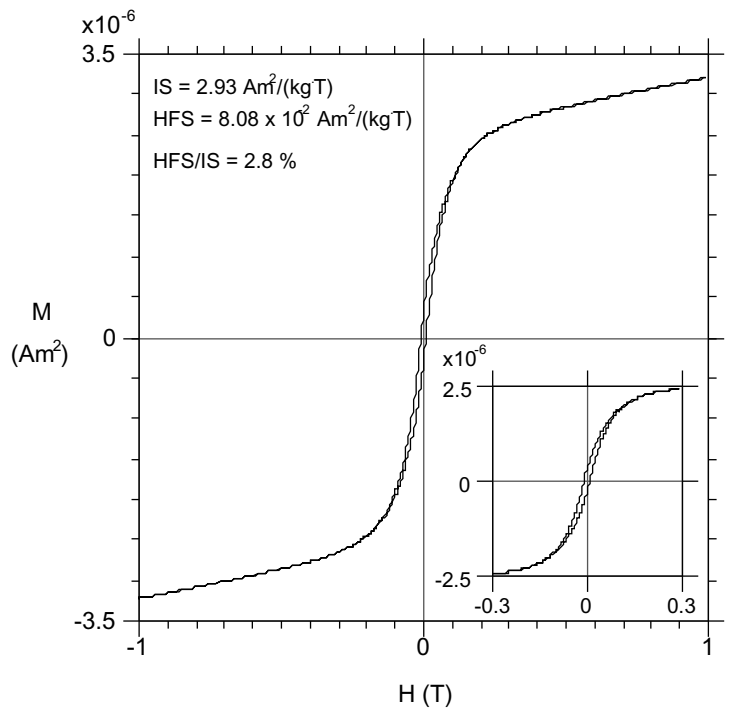

(b) 1109D-13R1, 68-70 cm (465.18 mbsf)

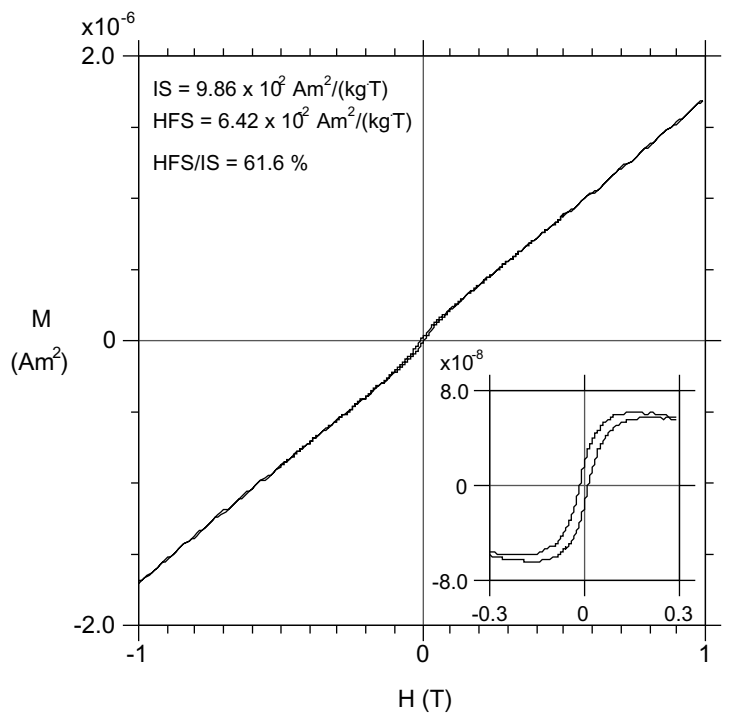

(d) $1109 \mathrm{C}-30 \times 1,87-89 \mathrm{~cm}(276.47 \mathrm{mbsf})$

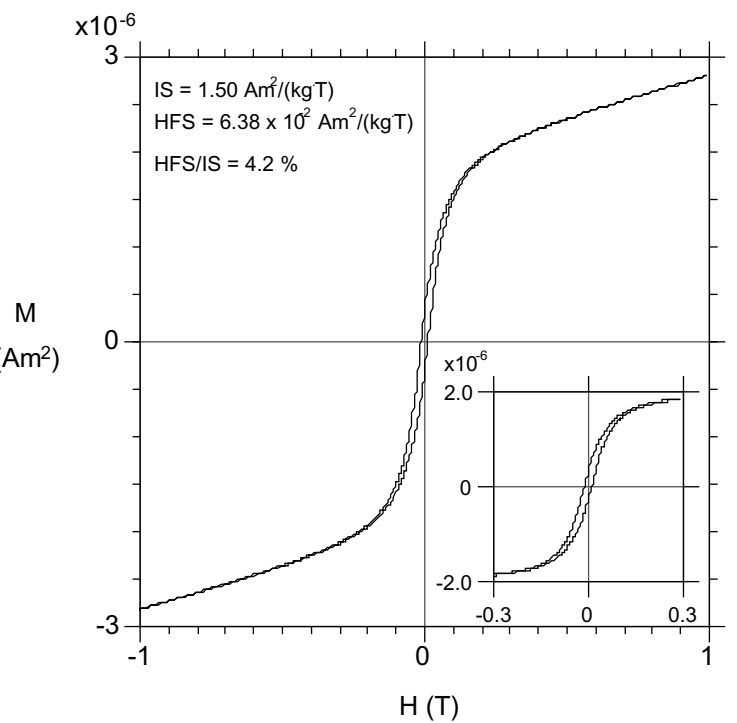

Fig. 7. Typical examples of hysteresis loops before (large) and after (small) high-field slope correction. The portions of the corrected loops are displayed between -0.3 and 0.3 . The values of initial slope (IS), high-field slope (HFS), and HFS/IS obtained through initial magnetization experiments are also shown. See the text for an explanation of these parameters.

The IS, $M_{s}$, and $M_{r}$ values at each site vary with a similar stratigraphic pattern to magnetic susceptibility variations (Figs. 4, 5, and 6). Zones with high and low values of these parameters are clearly identified at sites 1115 and 1109 , while samples from Site 1118 showed their gradual changes because of higher sedimentation rate (Figs. 3 and 6). In contrast to the IS value, the HFS value was relatively constant, although higher values were observed from the deepest sample at Site 1115 and below $670 \mathrm{mbsf}$ at Site 1109. There are upward decreases in HFS values above 80 mbsf at Site 1109 and above $140 \mathrm{mbsf}$ at Site 1115, where the IS, $M_{s}$, and $M_{r}$ values also decreased upward.

Variations in HFS/IS ratio were characterized by two distinct features; the high HFS/IS value above $25 \%$ and low value below $25 \%$. The zones with high HFS/IS values were identified as follows, which are shown as shaded zones in Figs. 4, 5, and 6; intervals between 515 and 475 mbsf, be- tween 412 and 284 mbsf, and between 246 and 218 mbsf at Site 1115, intervals between 708 and 673 mbsf, between 630 and $611 \mathrm{mbsf}$, between 548 and $403 \mathrm{mbsf}$, and between 388 and 380 mbsf at Site 1109, and a interval between 840 and $770 \mathrm{mbsf}$ at Site 1118. In the high HFS/IS zones, the IS, $M_{s}$, and $M_{r}$ values, as well as magnetic susceptibility, were low, while these parameters were high in the low HFS/IS zones. Samples from the high HFS/IS zones provided HLs dominated by a paramagnetic signal (Figs. 7(a), (b)). The corrected curves for linear high-field slope implied the presence of a high coercivity magnetic mineral; the ascending and descending portions of the HLs were closed at higher fields. Some samples provided constricted HLs (Fig. 7(b)), implying a mixture of magnetic minerals with large contrast in coercivity (Roberts et al., 1995; Tauxe et al., 1996). In the low HFS/IS zones, the ratio was generally less than $10 \%$, indicating a dominantly ferrimagnetic signal. HLs of sam- 

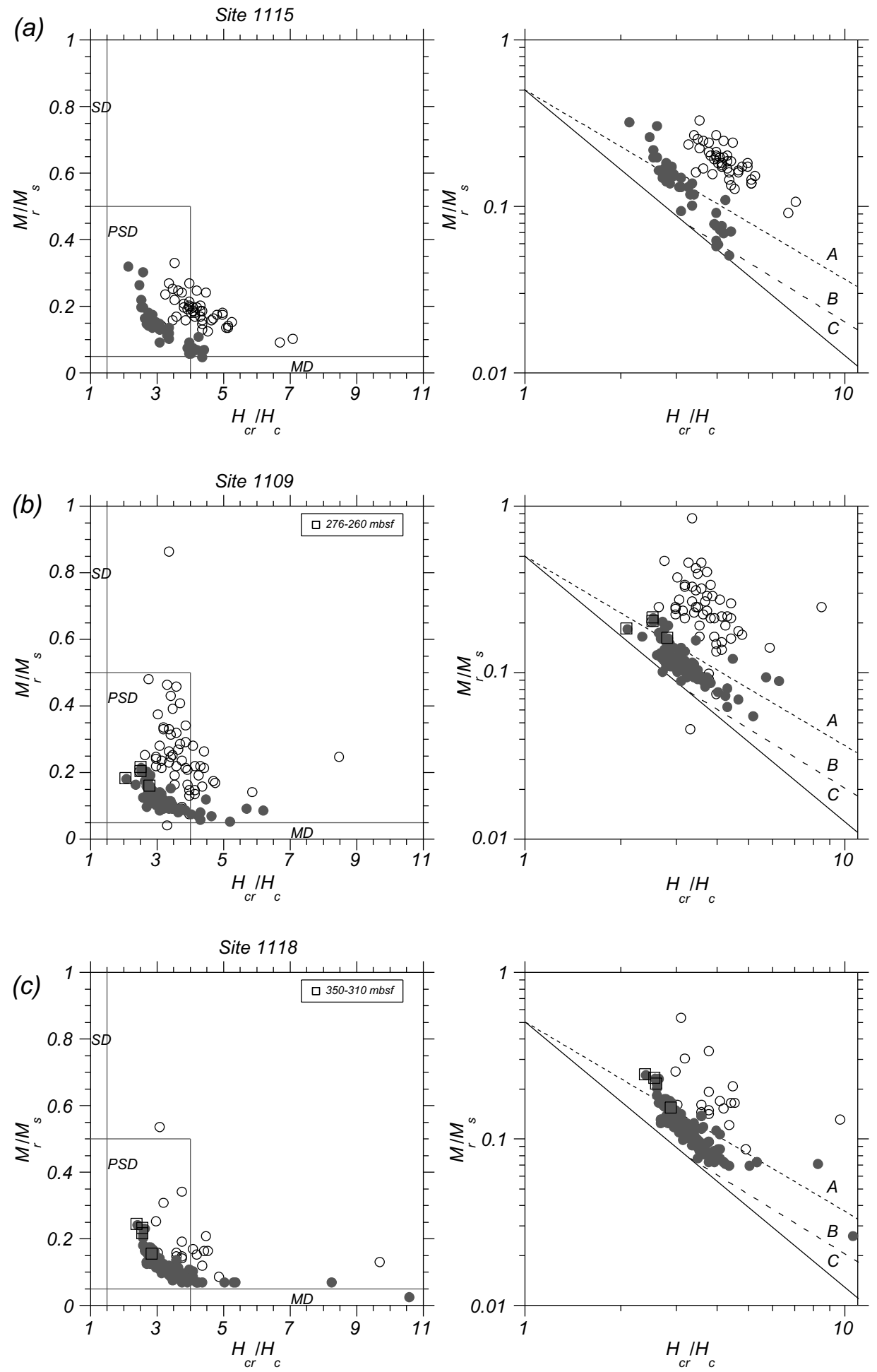

Fig. 8. Linear and bi-logarithmic plots of hysteresis parameters for sites 1109, 1115, and 1118. Solid (shaded) and open circles denote the data for samples with low HFS/IS below $25 \%$ and with high HFS/IS above $25 \%$, respectively. The data for samples in high coercivity zones (stippled zones in Figs. 5 and 6) at sites 1109 and 1118 are plotted with open square symbols. On linear plots, single domain (SD), pseudo-single domain (PSD), and multi-domain (MD) fields of Day et al. (1977) are also shown. On bi-logarithmic plots, the data of Parry (1980, 1982) for synthetic magnetite samples are shown for reference: line A, SD + MD mixtures; line B, PSD + MD mixtures; line C, single size (i.e., SD, PSD, or MD) magnetites.

ples from the low HFS/IS zones have a large contribution of ferrimagnetic signals (Figs. 7(c), (d)).

In the high HFS/IS zones, the $H_{c}$ and $H_{c r}$, especially $H_{c r}$, are relatively high, where the $H_{c r}$ values generally exceeded $30 \mathrm{mT}$, and $S(-0.1)$ and $S(-0.3)$ values were generally lower than 0.8 and 0.9 , respectively. In the low HFS/IS zones at sites 1109 and 1118, relatively high $H_{c}$ and $H_{c r}$ values also occur in the intervals between 276 and $260 \mathrm{mbsf}$ at Site 1109 and between 350 and 310 mbsf at Site 1118, which are shown as stippled zones in Figs. 5 and 6 . In these high coercivity intervals, almost all samples had low $S(-0.1)$ values below 0.8 , although $S(-0.3)$ values were higher than 
(a)

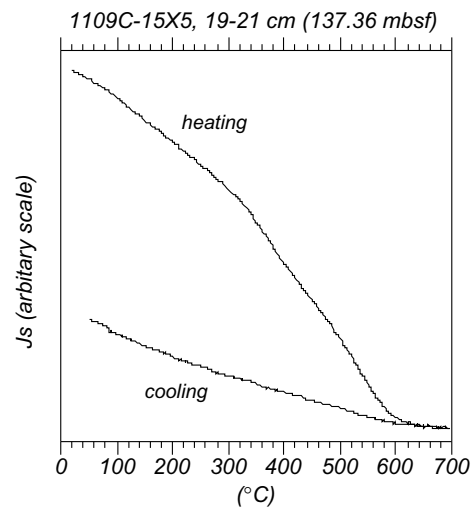

(b)

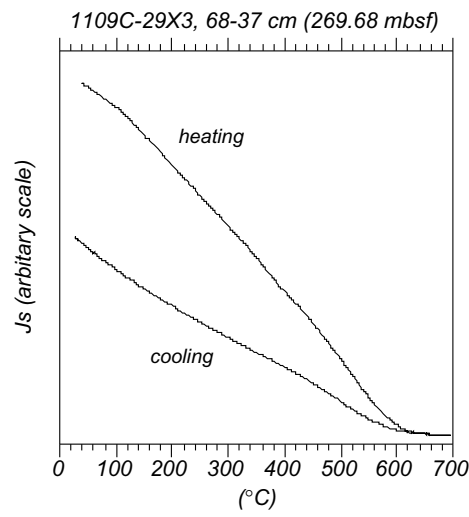

(c)

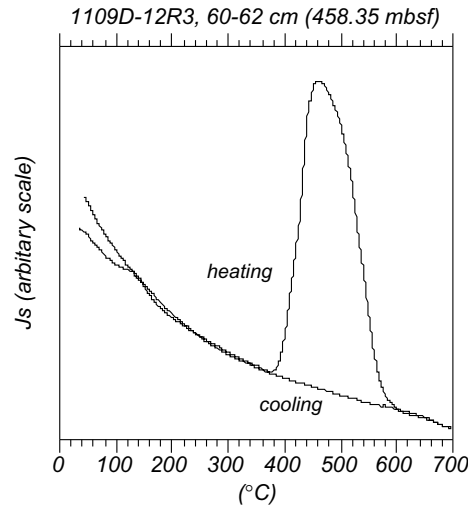

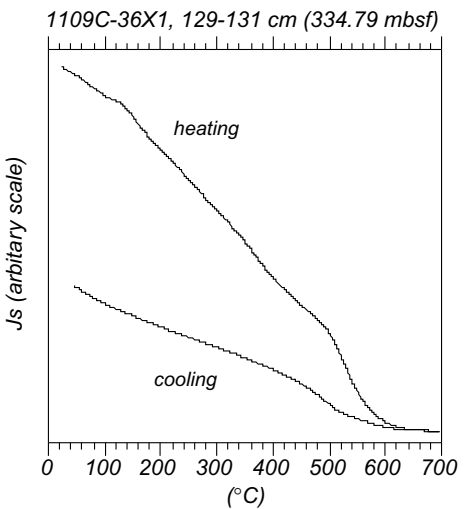
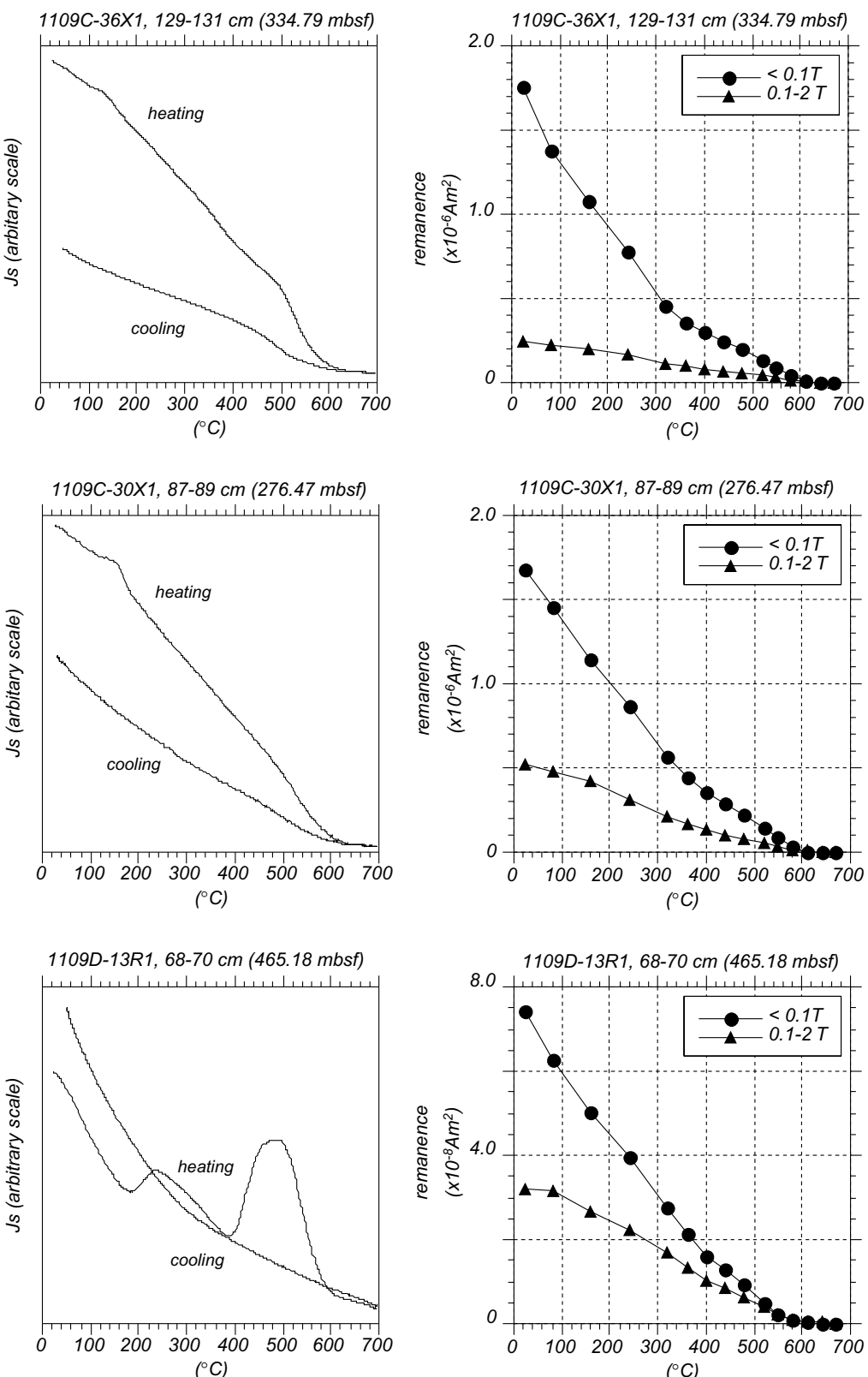

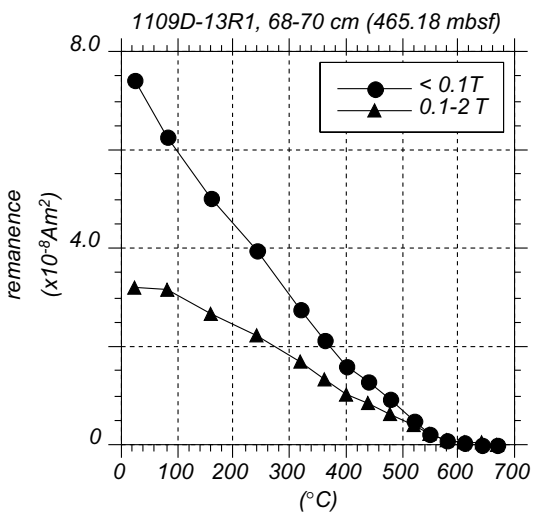

Fig. 9. Typical results of strong-field thermomagnetic experiments (left and center) and thermal demagnetization of composite IRMs (right) for selected samples. (a) Samples in low HFS/IS zones; (b) samples with relatively high coercivity in the low HFS/IS zones; (c) samples in high HFS/IS zones (see the text for an explanation).

0.9. Figure 7(d) is an example of HLs for samples from the high coercivity intervals, showing higher coercivity relative to the HL in Fig. 7(c). At Site 1115, samples in the section above $\sim 180 \mathrm{mbsf}$ in the low HFS/IS zone had high $H_{c}$ and $H_{c r}$ values, and $S(-0.1)$ values below 0.8 are frequently observed (Fig. 4).

In the high HFS/IS zones, $M_{r} / M_{S}$ is relatively high, although $H_{c r} / H_{c}$ or $M_{r} /$ IS values do not vary much. In the upper low HFS/IS zones, an upward increase of $M_{r} / M_{s}$ and decreases of $H_{c r} / H_{c}$ and $M_{r} /$ IS values were clearly observed between 215 and 170 mbsf at Site 1115 and between 320 and $280 \mathrm{mbsf}$ at Site 1109. At Site 1118, such changes seem to occur from 770 mbsf at the base of the upper low HFS/IS zone. The high coercivity intervals at sites 1109 (276-260 mbsf) and 1118 (350-310 mbsf) had maximum $M_{r} / M_{s}$ and
$M_{r} /$ IS values and minimum $H_{c r} / H_{c}$ ones.

$M_{r} / M_{s}$ and $H_{c r} / H_{c}$ values are plotted in Fig. 8 after Day et al. (1977). Data for samples in the low HFS/IS zones at each site fall mainly in the pseudo-single domain (PSD) region of Day et al. (1977), and fit a tight girdle showing a power-law relationship in a bi-logarithmic plot. The powerlaw relationships for a mixture of single domain (SD) and multi-domain (MD) magnetites (Parry, 1982) and for single size magnetites (Parry, 1980) form the girdle boundaries. The samples in the high coercivity intervals at sites 1109 and 1118 have relatively higher $M_{r} / M_{s}$ and lower $H_{c r} / H_{c}$ ratios. Data in the high HFS/IS zone are scattered and generally plotted in the region above the girdle of data from the low HFS/IS zone. 


\subsection{Thermomagnetic analysis and thermal demagneti- zation of IRMs}

Samples selected from the following three zones of Site 1109 were subjected to strong-field thermomagnetic experiments and thermal demagnetization experiments of composite IRMs. (1) The low HFS/IS zone, where the sediment has relatively lower coercivity (lower $H_{c r}$ and $H_{c}$ and $S(-0.1)$ above 0.8$)$, (2) the low HFS/IS zone which has higher coercivity than (1) (high $H_{c r}$ and $H_{c}$ and low $S(-0.1)$ below 0.8 ; the high coercivity intervals), and (3) the high HFS/IS zone which has high coercivity.

The samples from zones (1) and (2) have a slight inflection of the heating curve between 350 and $400^{\circ} \mathrm{C}$ which then decay to the Curie temperature of magnetite in air (Figs. 9(a), (b)). A loss of magnetization occurred between heating and cooling. Thermal demagnetization results of composite IRMs indicate an inflection at around $300-400^{\circ} \mathrm{C}$ and $580^{\circ} \mathrm{C}$ for the soft $(<0.1 \mathrm{~T})$ and hard $(0.1-2 \mathrm{~T})$ components (Figs. 9(a), (b)). These features suggest the presence of magnetite and maghemite in the samples from zones (1) and (2). No difference in magnetic behavior was observed between samples from zones (1) and (2) during the thermal experiments. Some samples showed a convex upward heating curve between 100 and $150^{\circ} \mathrm{C}$ during the thermomagnetic analysis. No remarkable change was observed in the IRM demagnetization curves in this temperature range. The change on the thermomagnetic curve may be attributed to thermal alteration of paramagnetic minerals instead of ferrior antiferro-magnetic minerals, which might have been associated with the decomposition of clay minerals (formation of magnetite from paramagnetic clay minerals and its oxidation to hematite in the higher temperature range).

Samples from zone (3) underwent a considerable increase in magnetization above $350^{\circ} \mathrm{C}$ during heating in air (Fig. 9(c)). The heating curves showed a magnetization peak at around $450^{\circ} \mathrm{C}$ and then decreased to the Curie temperature of magnetite. Some samples yielded a convex upward heating curve between 100 and $150^{\circ} \mathrm{C}$ or around $200^{\circ} \mathrm{C}$ (Fig. 9(c)). The soft and hard components of composite IRMs suggest an inflection at around $400^{\circ} \mathrm{C}$ and both components were completely demagnetized at $580^{\circ} \mathrm{C}$ (Fig. 9(c)). Thermomagnetic and demagnetization results also indicate the presence of magnetite and maghemite in samples from zone (3). No evidence for the existence of goethite and hematite was observed in the thermal demagnetization results of composite IRMs. Although some thermomagnetic curves imply the presence of hematite, it is considered to be an alteration product that formed during heating.

\section{Discussion}

Variations of magnetic susceptibility are consistent with variations of IS, $M_{s}$, and $M_{r}$ values, which are proxies for the concentration of magnetic minerals. The low and high HFS/IS zones represent the high and low susceptibility zones, respectively. The HFS/IS ratios indicate a dominant ferrimagnetic signal in the high susceptibility zones and a large contribution of paramagnetic minerals in the low susceptibility zone. Thermomagnetic analysis and thermal demagnetization of composite IRMs indicate the presence of magnetite and maghemite as the principal ferrimagnetic min- erals in the studied cores. The magnetic susceptibility therefore appears to be controlled by the relative concentration of these ferrimagnetic minerals.

$M_{r} / M_{s}$ and $H_{c r} / H_{c}$ ratios suggest that PSD magnetite and maghemite dominate in the high susceptibility zones (the low HFS/IS zones). Based on the values of $H_{c}, H_{c r}$, and S-ratios, the high coercivity intervals were recognized between 276 and 260 mbsf at Site 1109 and between 350 and $310 \mathrm{mbsf}$ at Site 1118. Rock magnetic parameters affected by grain size variation $\left(M_{r} / M_{s}, H_{c r} / H_{c}\right.$, and $M_{r} /$ IS $)$ indicate the presence of finer-grained ferrimagnetic minerals in these intervals. Those parameters also indicate an upward decrease in grain size of the ferrimagnetic minerals between 215 and 170 mbsf at Site 1115 and 320 and 280 mbsf at Site 1109. De Boer and Dekkers (1996) showed that the grain-size dependence of rock magnetic parameters for PSD maghemite is less prominent than for magnetite. Variations in the rock magnetic parameters for our samples may therefore mainly reflect the grain-size changes in magnetite.

The $H_{c}, H_{c r}$, and S-ratios values indicate the presence of high-coercivity magnetic minerals in the low susceptibility zones (the high HFS/IS zones). Results of the thermal experiments suggest the existence of magnetite and maghemite instead of goethite or hematite. Van Velzen and Zijderveld (1995) indicated that weathered SD magnetite can show extremely high coercivity $\left(H_{c r}\right.$ range $\left.36-188 \mathrm{mT}\right)$. After heating at $150^{\circ} \mathrm{C}$, IRM demagnetization curves of samples with weathered magnetite showed a large remanence loss, and the coercivity decreased to the normal values of SD magnetite. Van Velzen and Zijderveld (1995) attributed the enhanced coercivity to stress in magnetite grains induced by surface oxidation at low temperatures. Weathered magnetite may be a candidate for the high coercivity minerals in our samples. However, composite IRMs of our samples did not indicate remanence loss for thermal demagnetization at $160^{\circ} \mathrm{C}$, as was the case for the samples of Van Velzen and Zijderveld (1995). Further investigation will be needed to identify the high coercivity mineral in the low susceptibility zones.

The variations in magnetic properties indicate changes in concentration of magnetite and maghemite and in grain size of the ferrimagnetic minerals in the studied cores. Such changes may be attributed to change in depositional processes related to tectonic movements in the Woodlark Basin (changes in source materials, supply area, supply route, sedimentation rate, and so on) and/or post-depositional diagenetic change of magnetic minerals related to the chemical environment at the sites, which are also related to depositional processes (supplied materials and/or sedimentation rate; e.g., Berner, 1984; Verosub and Roberts, 1995). Variations in organic carbon and total sulfur contents in the studied cores are shown in Fig. 10 (Taylor et al., 1999b). The shipboard geochemical analysis pointed out that the abundance of organic carbon and sulfur was very low throughout the cores at the three sites; the average values of organic carbon content, for example, are $0.34 \mathrm{wt} \%$ for Site $1115,0.42$ $\mathrm{wt} \%$ for Site 1109 and $0.28 \mathrm{wt} \%$ for Site 1118 (Taylor et $a l ., 1999 b)$. There is no variation in the abundance of the two materials corresponding to variations in magnetic properties (Fig. 10). The effect of diagenetic change of magnetic minerals is less important for the first-order variation in mag- 
Site 1118

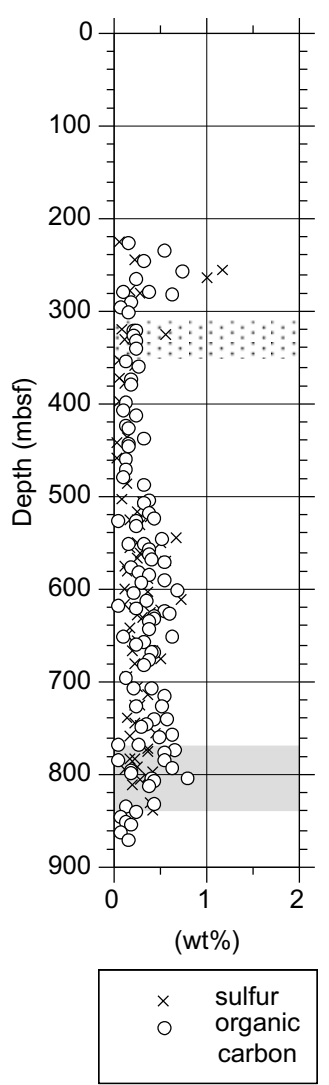

Site 1109

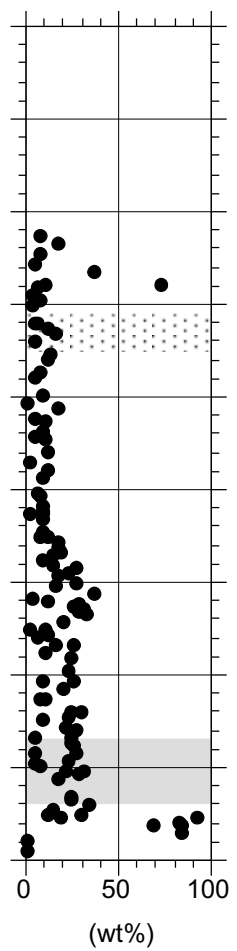

$\mathrm{CaCO}_{3}$

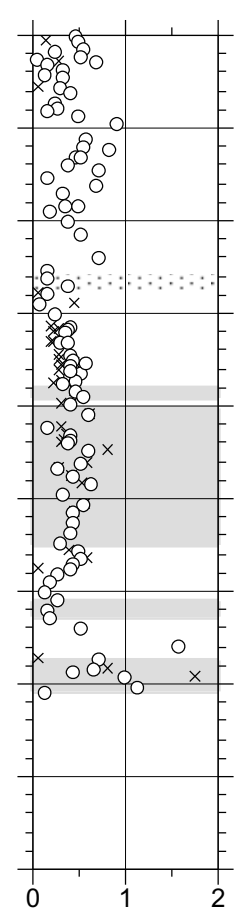

(wt\%)

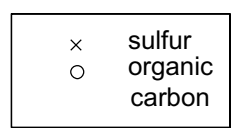

Site 1115
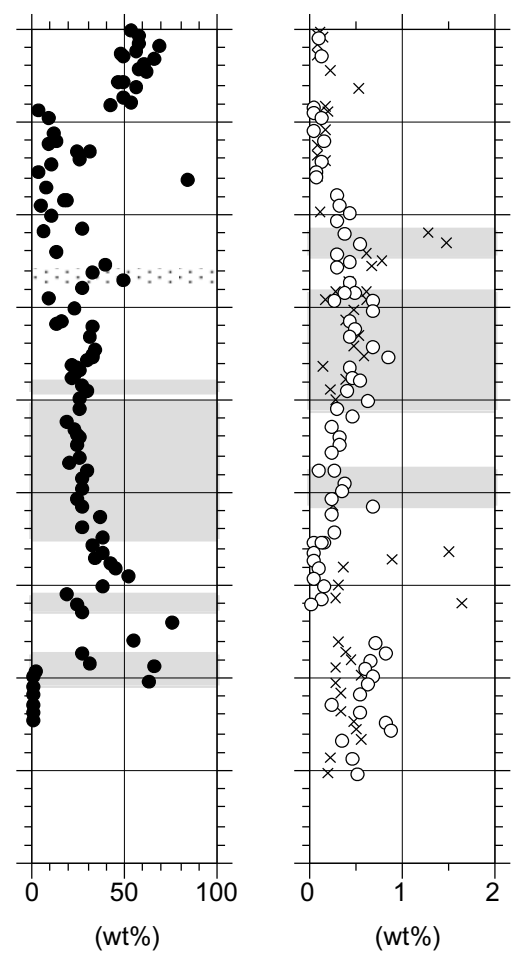

(wt\%)

$\mathrm{CaCO}_{3}$

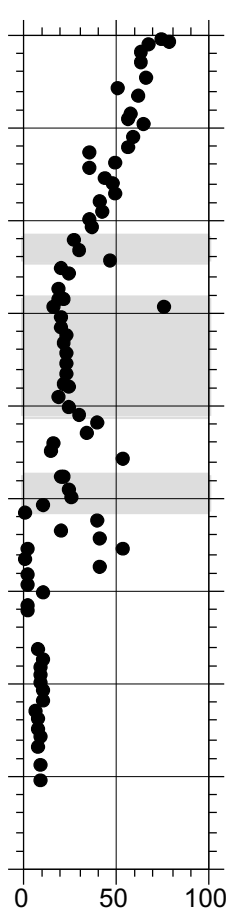

(wt\%)

$\mathrm{CaCO}_{3}$

Fig. 10. Organic carbon, total sulfur and $\mathrm{CaCO}_{3}$ profiles plotted against depth for sites 1109, 1115, and 1118, after Taylor et al. (1999b), with gray and stippled zones in Figs. 4, 5, and 6.

netic properties observed in the studied cores, although the existence of maghemite may imply a diagenetic influence on magnetite. We will thus discuss the concentration and grainsize changes in the ferrimagnetic minerals documented by the magnetic properties in terms of sedimentation processes related to the rifting of the Woodlark Basin.

An abrupt decrease in the concentration of ferrimagnetic minerals was recorded at around $415 \mathrm{mbsf}$ at Site 1115 and at around $550 \mathrm{mbsf}$ at Site 1109. Age data for the sedimentary successions (Takahashi et al., 2001) indicate that this change occurred at around 3.8 Ma (Fig. 3); a planktonic foraminifer datum indicates an age of $3.8 \mathrm{Ma}$ at $412.07-407.31 \mathrm{mbsf}$ in Site 1115 and at 551.0-548 mbsf in Site 1109. At 3.8 Ma, the sedimentation rate changed from $\sim 61$ to $\sim 296 \mathrm{~m} / \mathrm{m}$.y. at Site 1115 and from $\sim 98$ to $\sim 297 \mathrm{~m} / \mathrm{m}$.y. at Site 1109 (Takahashi et al., 2001). An abrupt increase of sedimentation rate, that is, an accelerated subsidence during rifting in the Woodlark Basin, may have caused a change in the depositional environment around sites 1115 and 1109. Changes in the source or supply route possibly resulted in the supply of sedimentary materials characterized by low concentrations of ferrimagnetic minerals.

An increase in the concentration of ferrimagnetic minerals was clearly distinguished at sites 1115,1109 , and 1118 . Based on age assignments for the sedimentary successions (Takahashi et al., 2001; Fig. 3), the onset of the change is slightly different at the three sites; as the distance of the site location from the normal fault at the Moresby Seamount in- creases, the age of the change becomes younger. At Site 1118 , the site nearest the Moresby Seamount, the gradual increase in concentration of ferrimagnetic minerals started at 770 mbsf. This depth is below the 744.5 mbsf of the bottom of the Mammoth subchron (3.33 Ma; Berggren et al., 1995), and is dated at about 3.4 Ma based on the sedimentation curve for Site 1118 (Takahashi et al., 2001; Fig. 3). At Site 1109, the next site to the north, the increase was recognized as being between 390 and $370 \mathrm{mbsf}$. An ${ }^{40} \mathrm{Ar} /{ }^{39} \mathrm{Ar}$ age of $3.27 \pm 0.03 \mathrm{Ma}$ was obtained from volcanic deposits between 372.2 and $371.6 \mathrm{mbsf}$ (Lackschewitz et al., 2001) at Site 1109 . The bottom of the Mammoth subchron was also identified at $384.5 \mathrm{mbsf}$. Therefore, the age of the change is constrained to about 3.3 Ma for Site 1109. At Site 1115, the site farthest from the Moresby Seamount, the change occurred around $215 \mathrm{mbsf}$, which is dated at about $3.2 \mathrm{Ma}$ (Fig. 3) based on an ${ }^{40} \mathrm{Ar} /{ }^{39} \mathrm{Ar}$ age of $3.23 \pm 0.08$ Ma between 243.44 and $243.44 \mathrm{mbsf}$ and the location of the bottom of the Kaena subchron (3.11 Ma; Berggren et al., 1995) at $202 \mathrm{mbsf}$. The age difference for the increase in concentration of ferrimagnetic minerals at the three sites suggests a northward onlapping of sediments with a high ferrimagnetic mineral concentration. This increase in concentration occurred during sedimentation at high accumulation rates at sites 1109 and 1118, and at a decreased rate at Site 1115 . Northward onlapping was probably related to subsidence at the area near the Moresby normal fault which produced subsidence at sites 1109 and 1118 . The change in concentration 
of ferrimagnetic minerals implies a change in source material or supply route and/or additional input of materials with higher concentrations of ferrimagnetic minerals (e.g., volcanic materials) in the source area or supply route. A change in sedimentary materials recorded in the cores at Site 1109 suggests a change in source material (Taylor et al., 1999b): the influx of clays and silts with altered calc-alkaline volcaniclastic materials and metamorphic detritus was observed in the section with high susceptibility between 380 and 83 mbsf, while in the underlying section with low susceptibility, there are hemipelagic carbonate muds with turbiditic sand interbeds from a dominantly basalt-andesite volcanic source.

The decrease in grain size is clearly observed between 215 and $170 \mathrm{mbsf}$ at Site 1115 and between 320 and 280 mbsf at Site 1109 . The onset of the change occurred at 3.1-3.0 Ma and was almost coeval with the decrease in the sedimentation rate at the two sites (Fig. 3); the rate decreased at about 3.0 Ma from 296 to $70 \mathrm{~m} / \mathrm{m} . \mathrm{y}$. for Site 1115 and from 229 to $69 \mathrm{~m} / \mathrm{m}$.y. for Site 1109 (Takahashi et al., 2001). The intervals with finer-grained ferrimagnetic minerals are recognized as being between 276 and 260 mbsf at Site 1109 and between 350 and $310 \mathrm{mbsf}$ at Site 1118. The age of these intervals is 2.3 to $2.0 \mathrm{Ma}$ (Fig. 3). These intervals were deposited during a period of relatively low sedimentation rate (Fig. 3); 69 m/m.y. for Site 1109 and $155 \mathrm{~m} / \mathrm{m} . y$. for Site 1118 (Takahashi et al., 2001). At sites 1109 and 1118, the increase in the sedimentation rate at about 2.0 Ma (Fig. 3) resulted in an increase in the grain size of the ferrimagnetic minerals (Figs. 5 and 6). At Site 1115, the section above $170 \mathrm{mbsf}$, which was deposited since $2.8 \mathrm{Ma}$ (Takahashi et al., 2001), contains finer-grained ferrimagnetic minerals and was deposited at low sedimentation rates below $100 \mathrm{~m} / \mathrm{m}$.y. (Fig. 3). An increase in the relative concentration of finergrained material is probably attributed to a decrease in the frequency and intensity of turbidity currents associated with decreasing sedimentation rate.

An upward decrease of HFS values was observed above $80 \mathrm{mbsf}$ at Site 1109 and above $140 \mathrm{mbsf}$ at Site 1115. The concentration of $\mathrm{CaCO}_{3}$ has high values $>40 \mathrm{wt} \%$ above 80 mbsf at Site 1109, and at Site 1115 an upward increase in $\mathrm{CaCO}_{3}$ content occurred above 300 mbsf, with high values $>40 \mathrm{wt} \%$ observed above $140 \mathrm{mbsf}$ (Fig. 10; Taylor et al., 1999b). The upper parts of the record at the two sites were deposited at middle bathyal depths (Fig. 3) and consist mainly of pelagic and turbiditic sediments (Taylor et al., 1999b). The $\mathrm{CaCO}_{3}$ concentration is probably influenced by the input of pelagic sediment. The upward decrease of HFS values may be attributed to an increase in the concentration of diamagnetic calcareous and/or siliceous materials in the pelagic sediments. The upward decrease in IS, $M_{s}$, and $M_{r}$ values, as well as magnetic susceptibility, is contemporaneous with the change of HFS values. A decrease in the concentration of ferrimagnetic minerals is suggested in the upper parts at the two sites. Sedimentation rates dropped below $100 \mathrm{~m} / \mathrm{m}$.y. above $50 \mathrm{mbsf}$ at Site 1109 and above 200 mbsf at Site 1115 (Fig. 3; Takahashi et al., 2001). An earlier decrease in sedimentation rate is inferred for the interval between 74 and $50 \mathrm{mbsf}$ at Site 1109 (ca. $118 \mathrm{~m} / \mathrm{m}$.y.; Takahashi et al., 2001). The decrease in sedimentation rates is probably associated with a decrease in the frequency of turbidity currents, with the decrease in ferrimagnetic mineral contents reflecting the decrease in turbidite frequency. The concentration of paramagnetic materials supplied by turbiditic currents may have also decreased. Taylor et al. (1999b) suggested a decrease in the volcaniclastic sand content deposited by turbidity currents in the upper part at Site 1115. As a result, an increase in the relative concentration of pelagic sediment may have occurred. This change in the sedimentation process probably influenced the variation of the HFS values in the upper parts of the sediment record at sites 1109 and 1115 .

\section{Conclusion}

Rock magnetic analyses were performed on synrift sediments of ODP sites 1109, 1115, and 1118 (Leg 180), located on the hanging wall margin north of the Moresby low-angle normal fault in the western Woodlark Basin. The principal magnetic minerals are PSD magnetite and maghemite. The concentration of ferrimagnetic minerals was found to control the magnetic susceptibility of the sediments. In low susceptibility zones, the paramagnetic contribution to the magnetic signal was large. An abrupt decrease in the concentration of ferrimagnetic minerals occurred at around 3.8 Ma at sites 1109 and 1115 , which was coeval with an increase in the sedimentation rate. A change in the rifting process in the Woodlark Basin caused a change in the depositional environment around sites 1109 and 1115 (i.e., source or supply route). An increase in ferrimagnetic mineral concentration occurred at $3.4 \mathrm{Ma}$ at Site 1118, 3.3 Ma at Site 1109, and 3.2 Ma at Site 1115. The farther the distance of the site location from the Moresby normal fault, the younger the onset age of the change in ferrimagnetic mineral concentration. The age difference of the change at the three sites suggests a northward onlapping of sediments with high concentrations of ferrimagnetic minerals. The northward onlapping of the sediments was probably related to subsidence at the area near the Moresby normal fault, which produced subsidence at sites 1109 and 1118. A decrease in grain size of the ferrimagnetic minerals occurred at 3.1-3.0 Ma at sites 1109 and 1115 , coeval with a decrease in sedimentation rate. Sediments with finer-grained ferrimagnetic minerals deposited at 2.3-2.0 Ma at sites 1109 and 1118 and later $2.8 \mathrm{Ma}$ at Site 1115 , during sedimentation at low accumulation rates. The decreased frequency and intensity of turbidity currents may have caused an increase in the concentration of finegrained magnetic minerals. The upper parts of the record at sites 1109 and 1115, which were deposited at low sedimentation rates, also contain diamagnetic contributions and a decrease in the concentration of ferrimagnetic minerals. The upper parts contain pelagic sediments and have high $\mathrm{CaCO}_{3}$ concentrations. Low frequency of turbidites supplying ferrimagnetic and paramagnetic minerals may have resulted in relatively high concentrations of diamagnetic materials.

Acknowledgments. We would like to acknowledge the critical reviews and helpful suggestions of Drs. A. P. Roberts and M. Okada. We thank all participants of the Leg 180 Shipboard Scientific Party, the technicians, and the crew. This research used samples and data provided by the Ocean Drilling Program (ODP) which is sponsored by the U.S. National Science Foundation (NSF) and participating countries under management of Joint Oceanographic Institutions 
(JOI), Inc. One of the authors (G. M. Frost) used funding partially provided by JOI/USSSP \#180-F000901 and \#180-F000975 for this research.

\section{References}

Berggren, W. A., D. V. Kent, C. C. Swisher, III, and M. P. Aubry, A revised Cenozoic geochronology and chronostratigraphy, in Geochronology, Time Scales and Global Stratigraphic Correlation, SEPM Spec. Publ., edited by W. A. Berggren, D. V. Kent, M. P. Aubry, and J. Hardenbol, pp. 129-212, 1995.

Berner, R. A., Sedimentary pyrite formation: An update, Geochim. Cosmochim. Acta., 48, 605-615, 1984.

Day, R., M. Fuller, and V. A. Schmidt, Hysteresis properties of titanomagnetites: grain-size and compositional dependence, Phys. Earth Planet. Inter., 13, 260-267, 1977.

De Boer, C. D. and M. J. Dekkers, Grain-size dependence of the rock magnetic properties for a natural maghemite, Geophys. Res. Lett., 23, 2815-2818, 1996.

Lackschewitz, K. S., P. V. D. Bogaard, and D. F. Mertz, ${ }^{40} \mathrm{Ar} /{ }^{39} \mathrm{Ar}$ ages of fallout tephra layers and volcaniclastic deposits in the sedimentary succession of the western Woodlark Basin, Papua New Guinea: The marine record of Miocene-Pleistocene volcanism, in Non-volcanic Rifting of Continental Mragins: Evidence from Land and Sea, Geol. Soc. Spec. Publ., 187, edited by R. C. L. Wilson et al., 373-388, 2001.

Lowrie, W., Identification of ferromagnetic minerals in a rock by coercivity and unblocking temperature properties, Geophys. Res. Lett., 17, 159-162, 1990.

King, J. W. and J. E. T. Channell, Sedimentary magnetism, environmental magnetism, and magnetostratigraphy, U.S. Natl. Rep. Int. Union Geod. Geophys. 1987-1990, Rev. Geopys., 29, 358-370, 1991.

Parry, L. G., Shape-related factors in the magnetization of immobilized magnetite particles, Phys. Earth Planet. Inter., 22, 144-154, 1980.

Parry, L. G., Magnetization of immobilized particle dispersions with two distinct particle sizes, Phys. Earth Planet. Inter., 28, 230-241, 1982.

Roberts, A. P., Y. Cui, and K. L. Verosub, Wasp-waisted hysteresis loops: Mineral magnetic characteristics and discrimination of components in mixed magnetic systems, J. Geophys. Res., 100, 17909-17924, 1995.
Takahashi, K., G. Cortese, G. M. Frost, S. Gerbaudo, A. M. Goodliffe, N. Ishikawa, K. S. Lackschewitz, R. C. B. Perembo, J. M. Resig, W. G. Siesser, B. Taylor, and M. Testa, Summary of revised age assignments for ODP Leg 180, in Proc. ODP, Sci. Results, 180, edited by P. Huchon, B. Taylor, A. Klaus et al., 2001.

Tauxe, L., T. A. T. Mullender, and T. Pick, Potbellies, wesp-waists, and superparamagnetism in magnetic hysteresis, J. Geophys. Res., 101, 571583, 1996.

Taylor, B. and N. F. Exon, An investigation of ridge subduction in the Woodlark-Solomons region: Introduction and overview, in Marine Geology, Geophysics and Geochemistry of the Woodlark Basin-Solomon Islands, Earth Sci. Ser, 7, edited by B. Taylor and N. F. Exon, pp. 124, Circum-Pacific Council For Energy and Mineral Resources, Houston, Tex, 1987.

Taylor, B., A. Klaus, A. Goodliffe, F. Martinez, and R. Hey, Continental rifting and initiation of sea-floor spreading in the Woodlark Basin, Nature, 374, 534-537, 1995 .

Taylor, B., A. Klaus, A. Goodliffe, and F. Martinez, How continents break up: Insights from Papuan New Guinea, J. Geophys. Res., 104, 74977512, 1999a.

Taylor, B., P. Huchon, A. Klaus, et al., Proc. ODP, Init. Repts., 180, Active Continental Extension in the Western Woodlark Basin, Papua New Guinea [CD-ROM], Available from: Ocean Drilling Program, Texas A\&M University, College Station, TX 77845-9547, U.S.A., 1999 b.

Thompson, R. and F. Oldfield, Environmental Magnetism, Allen and Unwin, Winchester, Mass., 277 pp., 1986.

Van Velzen, A. J. and J. D. Zijderveld, Effects of weathering on singledomain magnetite in Early Pliocene marine marls, Geophys. J. Int., 121, 267-278, 1995.

Verosub, K. L. and A. P. Roberts, Environmental magnetism: Past, present, and future, J. Geophys. Res., 100, 2175-2192, 1995.

Weissel, J. K., B. Taylor, and G. D. Kaener, The opening of the Woodlark Basin, subduction of the Woodlark spreading system and evolution of northern Melanesia since mid-Pliocene time, Tectonophys., 87, 253-277, 1982.

N. Ishikawa (e-mail: ishikawa@gaia.h.kyoto-u.ac.jp) and G. M. Frost 